\title{
PLANT SPECIES RICHNESS AT DIFFERENT SCALES IN NATIVE AND EXOTIC GRASSLANDS IN SOUTHEASTERN ARIZONA
}

\author{
Steven P. McLaughlin ${ }^{1}$ and Janice E. Bowers ${ }^{2,3}$
}

\begin{abstract}
Species richness in Madrean mixed-grass prairies dominated by native or exotic species in southeastern Arizona was characterized at the community and point scales using ten $1-\mathrm{m}^{2}$ quadrats nested within each of eight 1000 $\mathrm{m}^{2}$ plots. In the $1000-\mathrm{m}^{2}$ plots average richness was significantly higher in oak savanna (OS, 121.0 species) than in exotic grassland on mesa tops (EMT, 52.0 species), whereas native grassland on mesa slopes (NMS, 92.5 species) and native grassland on mesa tops (NMT, 77.0 species) did not differ significantly in richness from OS or EMT. When richness was partitioned by life form, EMT was notably poorer than other community types in species of perennial grasses, perennial herbs, and summer annuals. In the 1- $\mathrm{m}^{2}$ quadrats, OS (21.2 species), NMS (20.9 species), and NMT (20.7 species) were significantly richer than EMT (5.9 species). Cover in $1-\mathrm{m}^{2}$ plots was significantly higher in EMT than in NMT, NMS, or OS. Species richness at the point scale showed a unimodal relation to canopy cover, with cover accounting for $30 \%$ of the variation in number of species in $1-\mathrm{m}^{2}$ quadrats. Competitive exclusion and allelopathy have perhaps limited species richness at the point scale in exotic grassland. There was no evidence of a species-pool effect between point and community scales, but such an effect between community and landscape scales was supported. Madrean mixed-grass prairies are landscapes with high species richness in comparison to other grassland types in North America, providing a large pool of potential colonizing species at the community scale. Beta-diversity (between communities) within the landscape of the Appleton-Whittell Research Ranch was consequently high despite a relative lack of habitat diversity.
\end{abstract}

Key words: species richness, grasslands, exotic species, invasive species, species pools, Madrean mixed-grass prairie, Arizona.

Eragrostis curvula (Schrad.) Nees var. conferta Stapf (Boer lovegrass) and E. lehmanniana Nees (Lehmann lovegrass), $\mathrm{C}_{4}$ perennial grasses native to South Africa, were planted in many places in southeastern Arizona in the 1930s and 1940s. These species have had marked impacts on native grasslands in the region, including altered fire frequency (Cable 1971, Anable et al. 1992); reduced diversity and abundance of native rodents, grasshoppers, and birds (Bock et al. 1986); reduced cover of native shrubs, grasses, and herbs (Bock et al. 1986); and reduced richness of native herbs and grasses (Bock et al. 1986). Efforts to remove these exotics by burning, mowing, mulching, and chemical application have been largely ineffective or extremely costly, and both species have continued to spread in native grasslands since they were introduced (Cable 1971, Anable et al. 1992).

Given this persistent threat to biodiversity of grassland communities, we undertook a baseline study at a grassland site protected from domestic livestock grazing for nearly 30 years.
Our objectives were to characterize plant species richness in southeastern Arizona grassland at multiple spatial scales and to compare native-dominated and exotic-dominated communities in terms of species richness and lifeform diversity. A previous study of grassland diversity at our site (Bock et al. 1986) sampled point-scale species richness in small quadrats of unspecified size centered on 72 points along line transects. Because measures of diversity are scale dependent (Huston 1999, Loreau 2000), we assessed species richness at the community $\left(1000-\mathrm{m}^{2}\right)$ and point $\left(1-\mathrm{m}^{2}\right)$ scales. Numerous studies worldwide have used 1000$\mathrm{m}^{2}$ plots to examine richness at the community scale (Gentry 1988). Because estimates of diversity vary widely according to sampling season and effort (West and Reese 1991, Klimes et al. 2001), we determined cumulative species number by sampling 2-3 times during the growing season for several years. Finally, because species richness has been reported to increase with community productivity to a certain point and then decrease as competitive 
exclusion drives out less competitive species (Huston 1979, Tilman 1982, 1993), we compared native and exotic grassland using canopy cover at the point scale as a measure of productivity.

\section{Study Area}

Our study area was the Appleton-Whittell Research Ranch (hereafter "Research Ranch") in northeastern Santa Cruz County, Arizona. This 3240-ha reserve is owned and operated by the National Audubon Society. The Research Ranch is located at $31^{\circ} 35^{\prime} \mathrm{N}, 110^{\circ} 30^{\prime} \mathrm{W}$ and lies between $1417 \mathrm{~m}$ and $1570 \mathrm{~m}$ above sea level. The flora comprises 473 native species and 38 exotic species (McLaughlin et al. 2001). The Research Ranch has not been grazed by domestic livestock since 1969 (Bock and Bock 1986).

The topography of the Research Ranch is of nearly level mesas dissected by broad or narrow drainages. Grasslands occur on the mesa tops, and oak savannas are found in shallow drainages and on east- and north-facing slopes of major ravines. The grassland has been described as Madrean mixed-grass prairie (Bock and Bock 2000) and is dominated by $\mathrm{C}_{4}$ perennial bunchgrasses, primarily Bouteloua gracilis (Kunth) Lag., B. curtipendula (Michx.) Torr., and Eragrostis intermedia Hitchc. Stands dominated by the exotic grasses Eragrostis curvula and E. lehmanniana are confined mostly to mesa tops. Eragrostis curvula was seeded at the Research Ranch in 1949 (Audubon Research Ranch 2003) and probably has not spread far beyond the original plantings (J. Bock personal communication). Oak savanna at the Research Ranch is typical Madrean evergreen woodland (Brown 1982) with an overstory of Quercus emoryi Torr., Q. arizonica Sarg., and Q. oblongifolia Torr.

At the nearest long-term weather station (Canelo, Arizona, a distance of about $5 \mathrm{~km}$ from the Research Ranch), average annual precipitation from 1910 to 2003 was $460 \mathrm{~mm}$; mean temperature in June, the hottest month, was $32.4^{\circ} \mathrm{C}$; and mean temperature in January, the coldest month, was $-3.3^{\circ} \mathrm{C}$ (WRCC 2004). About two-thirds of the annual precipitation arrives in summer (July-September; Bock and Bock 1986). The winter rainy season is less welldefined but generally lasts from November through February.

\section{Methods \\ Data Collection}

Although Eragrostis lehmanniana appears to be more widespread at the Research Ranch than E. curvula, the latter has stronger dominance where it occurs, suggesting that its effects on native species might be more pronounced than those of E. lehmanniana. Therefore, in our comparison of exotic and native grassland, we focused on E. curvula. In September 1997 we established a single $1000-\mathrm{m}^{2}$ plot $(50 \mathrm{~m} \times 20 \mathrm{~m})$ in each of 3 plant communities: oak savanna (OS), native grassland on a mesa slope (NMS), and exotic grassland on a mesa top (EMT). The EMT plot was dominated by E. curvula, the other plots by mixtures of native species. We established a 2nd plot in each community type in April 1998. In August 1999 we established 2 additional 1000$\mathrm{m}^{2}$ plots in native grassland on mesa tops (NMT). Plot placement was essentially at random in EMT and NMT, which occupy large patches at the Research Ranch. Patches of OS and NMS are much smaller at the study area, and we centered our plots within patches of suitable size. In all cases, we chose plot locations solely on the basis of vegetation physiognomy and not on any a priori evaluation of their species richness. Mapped soil type (White House gravelly loam) was the same for all plots. Fire history of the plots varied, but none burned between July 1987 and April 2002 (L. Kennedy personal communication). Within each plot we randomly placed ten $1-\mathrm{m}^{2}$ quadrats $(0.5 \mathrm{~m} \times$ $2.0 \mathrm{~m})$. Quadrats were established in the OS, NMS, and EMT plots in June 1999 and in the NMT plots in August 1999. Plots and quadrats were permanently marked with metal stakes.

We recorded all plant species present in the entire plot and in each of the quadrats at the time of establishment; during successive inventories we noted any additional species. Plots in OS, NMS, and EMT were reinventoried in May 1998, July 1998, August 1998, and September 1998. Plots and quadrats in all 4 community types were reinventoried in September 1999, October 1999, April 2000, and May 2001. At the end of the study, we determined species richness (cumulative number of species) for each plot and quadrat. We estimated total herbaceous cover $(\%)$ in each $1-\mathrm{m}^{2}$ quadrat in late August 1999 at the peak of the growing season. Two observers estimated percent 


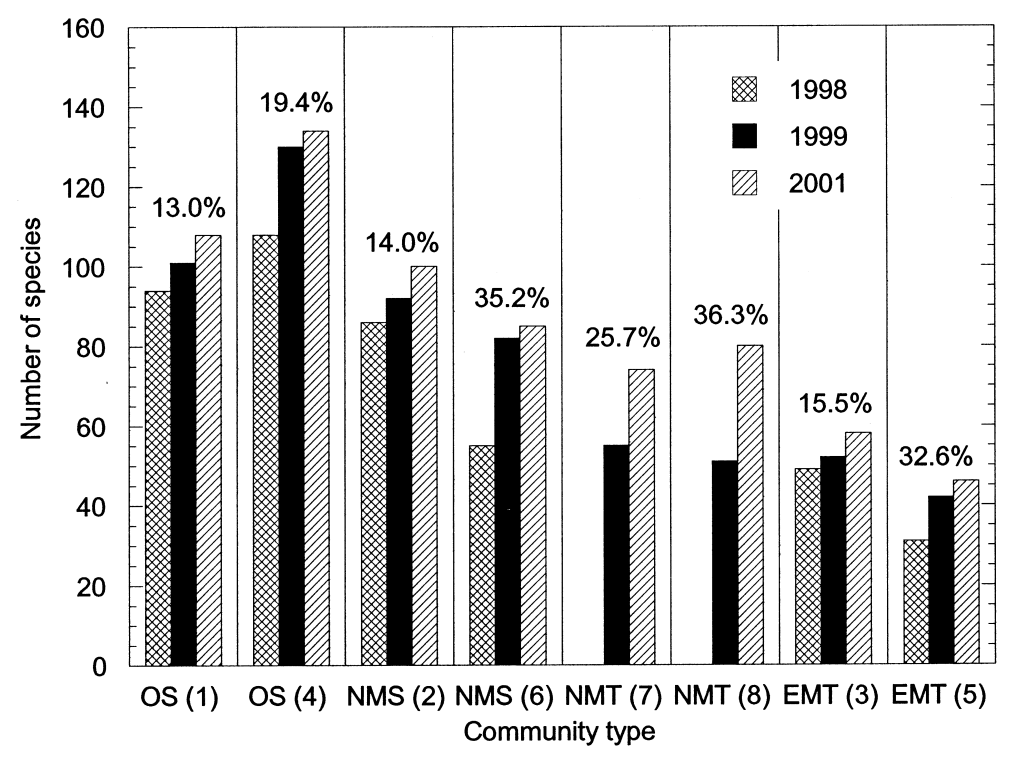

Fig. 1. Temporal change in species richness in 4 community types and 8 plots at the Research Ranch, Arizona. Values above bars denote percent change in number of species between first year and final year of measurement. Community types: OS = oak savanna, NMS = native grassland on mesa slopes, NMT = native grassland on mesa tops, EMT = exotic grassland on mesa tops. Plot numbers shown in parentheses.

cover independently; these values were averaged to give an average cover value for each quadrat.

\section{Data Analysis}

We used separate analyses of variance (ANOVA) followed by post hoc Tukey pairwise multiple comparisons to see if the 4 community types (OS, NMS, NMT, EMT) differed significantly in species richness at the community or point scales. For the point scale we produced a dominance-diversity curve by ranking all species in the 80 quadrats by frequency and then plotting the frequency distribution as a function of rank (Whittaker 1975). To compare canopy cover in $1-\mathrm{m}^{2}$ quadrats among the 4 community types, we used ANOVA followed by post hoc Tukey pairwise multiple comparisons. We used nonlinear regression to examine the relation between cover and species richness in $1-\mathrm{m}^{2}$ quadrats. To compare diversity of life forms among community types we assigned each species to 1 of 8 life forms: winter annual, summer annual, biennial, perennial herb, perennial grass, succulent, shrub, or tree. We used separate chi-square tests to compare plots in terms of species richness (number of species) of winter annuals, summer annuals, perennial herbs, perennial grasses, succulents, and shrubs.

\section{Results}

\section{Species Richness}

In our 8 community-scale plots $\left(1000 \mathrm{~m}^{2}\right)$ we recorded a total of 233 species, finding $45.6 \%$ of the flora of the Research Ranch in just $0.025 \%$ of the area. This is not surprising since OS, NMS, NMT, and EMT are the major community types at the Research Ranch, occupying $>90 \%$ of its areal extent. Species known from the Research Ranch flora but not found on our plots were mostly plants of riparian habitats, disturbed areas, or rare substrates such as rock outcrops. Richness on the plots increased with sampling effort (i.e., number of years; Fig. 1); from first to final year of sampling, the average increase across all plots was $24.0 \%$. Cumulative number of species (2 plots per community type) was OS $(134,108)$; NMS (100, $85)$; NMT $(80,74)$; and EMT $(58,46)$. There were significant differences in richness among community types $(F=12.35, P=0.02)$ because of the contrast between EMT and OS $(P=$ 0.01). NMS, NMT, and EMT did not differ significantly in richness even though they did 


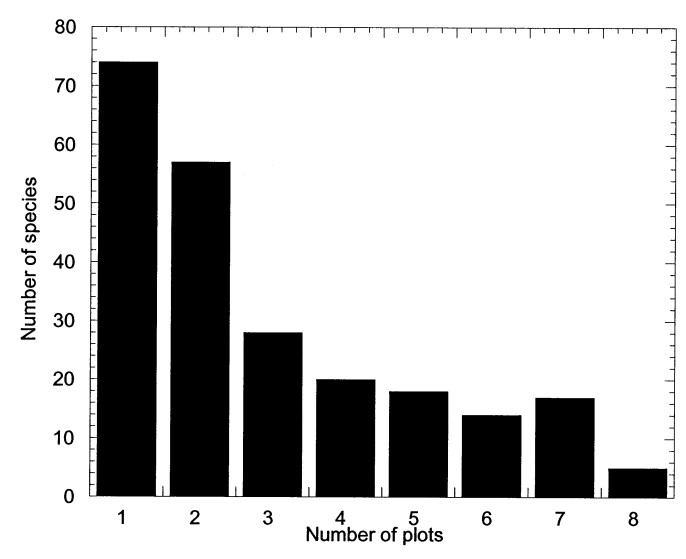

Fig. 2. Frequency distribution (numbers of species recorded from 1 to 8 plots) at the community scale at the Research Ranch, Arizona.

not overlap in numbers of species; small sample size undoubtedly contributed to the lack of significance. Most species at this scale were recorded from just 1 or 2 plots (Fig. 2). In the 8 plots we found only 4 exotic species distributed as follows: OS $(2,1)$; NMS $(1,1)$; NMT $(4,2)$; EMT $(2,2)$. Total species richness was thus due almost entirely to native species.

In our 80 point-scale quadrats $\left(1 \mathrm{~m}^{2}\right)$, we found a total of 148 species. The dominancediversity curve for this sample, based on frequency of occurrence, was essentially lognormal in shape (Fig. 3). Point-scale richness averaged 21.2 species $\cdot \mathrm{m}^{-2}$ in OS, 20.9 species $\cdot \mathrm{m}^{-2}$ in NMS, 20.7 species $\cdot \mathrm{m}^{-2}$ in NMT, and 5.9 species $\cdot \mathrm{m}^{-2}$ in EMT. On average, quadrats in EMT supported $72 \%$ fewer species $\cdot \mathrm{m}^{-2}$ than quadrats in other community types. Analysis of variance showed that there were significant differences in point-scale richness among community types $(F=9.85, P=0.03)$ because of the contrasts between EMT and each of the other 3 types $(P=0.04)$. Richness of the ten $1-\mathrm{m}^{2}$ quadrats was positively related to richness of the corresponding $1000-\mathrm{m}^{2}$ plot $\left(r^{2}=0.59, P=0.04\right.$; Fig. 4$)$. However, this effect was due entirely to the EMT plots. When the EMT plots were removed, there was no relation between point- and community-scale richness for the OS, NMS, and NMT plots (Fig. 4).

\section{Cover and Richness}

Canopy cover ranged from $40.4 \%$ to $79.6 \%$ (Table 1). Community types differed signifi-

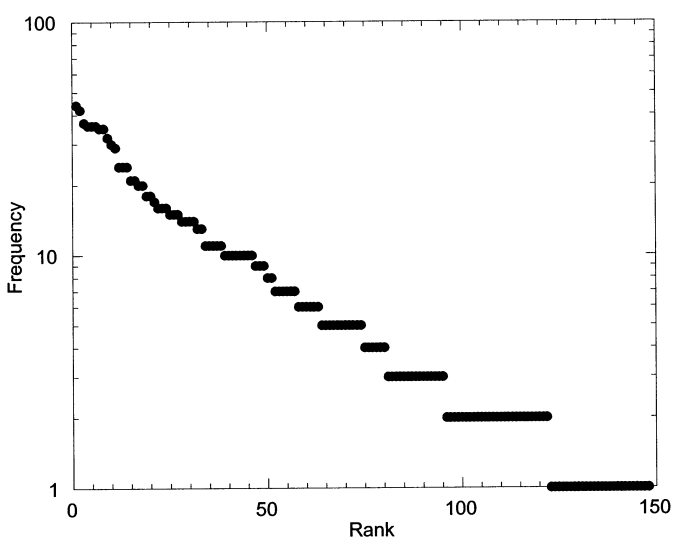

Fig. 3. Dominance-diversity curve based on frequencies of species in eighty $1-\mathrm{m}^{2}$ quadrats at the Research Ranch, Arizona. Species were ranked by their frequency values along the $\mathrm{x}$-axis from high to low frequency.

cantly in cover $(F=19.82, P<0.001$; Table 1$)$; in particular, cover of EMT was significantly higher than that of NMT $(P=0.047)$, NMS $(P$ $<0.001)$, and OS $(P<0.001)$. Species richness at the point scale showed a unimodal relation to canopy cover when all community types were included in the regression (Fig. 5), with cover accounting for $30 \%$ of the variation in number of species in 1-m² quadrats. Without EMT quadrats, however, the relation between canopy cover and species richness no longer held $\left(r^{2}\right.$ $=0.02)$.

\section{Life Form Diversity and Species Abundance}

On the $1000-\mathrm{m}^{2}$ plots, perennial herbs and summer annuals comprised $43.4 \%$ and $22.3 \%$ of the combined plot floras. Perennial grasses, winter annuals, and shrubs were $12.9 \%, 9.9 \%$, and $5.2 \%$ of the combined plot floras. Trees, biennials, and succulents were minor components $(<5 \%)$. Chi-square tests showed significant differences among plots in number of species of summer annuals $\left(\chi^{2}=46.3, P<\right.$ $0.001)$, perennial herbs $\left(\chi^{2}=17.2, P=0.016\right)$, and perennial grasses $\left(\chi^{2}=16.9, P=0.018\right)$. In particular, EMT was notably poorer in species of perennial herbs, perennial grasses, and summer annuals than other community types (Table 2). Plots differed little in number of species of shrubs, winter annuals, or succulents.

Of the 30 most frequent species (Table 3), only 3 were recorded from half or more of the 80 quadrats. Although the vegetation is clearly 


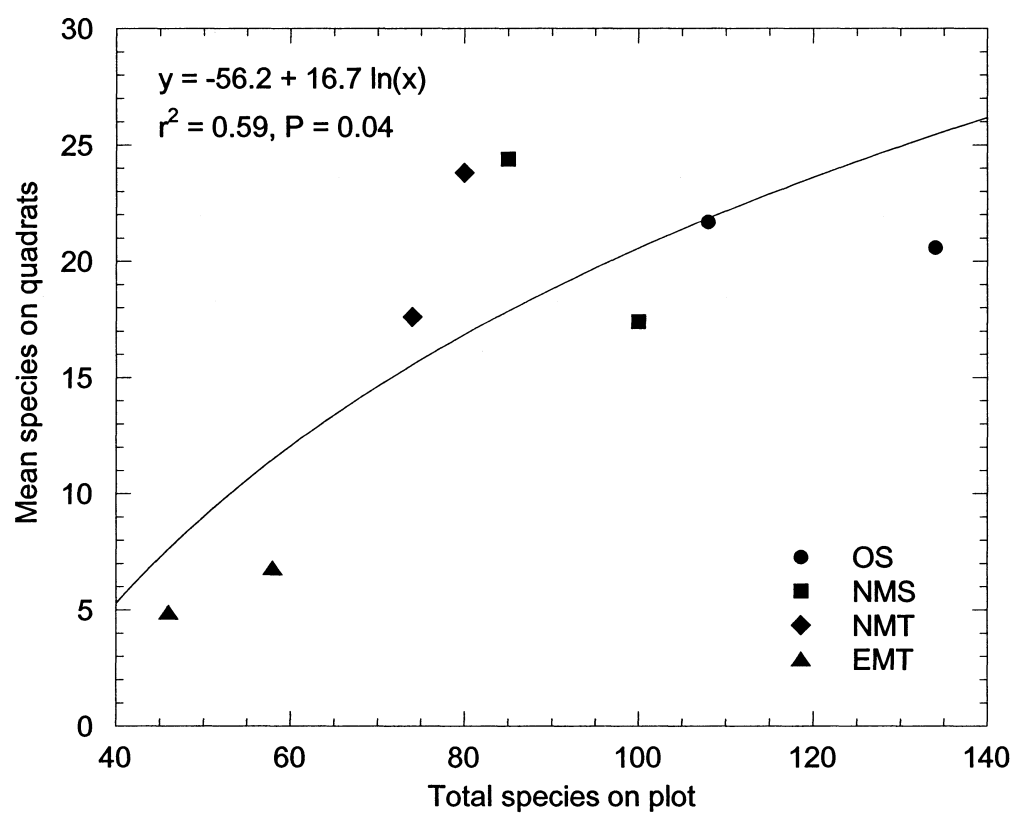

Fig. 4. Relation between number of species in $1000-\mathrm{m}^{2}$ plots (x-axis) and mean number of species in ten $1-\mathrm{m}^{2}$ quadrats (y-axis) at the Research Ranch, Arizona. Community types: OS = oak savanna, NMS = native grassland on mesa slopes, NMT = native grassland on mesa tops, EMT = exotic grassland on mesa tops.

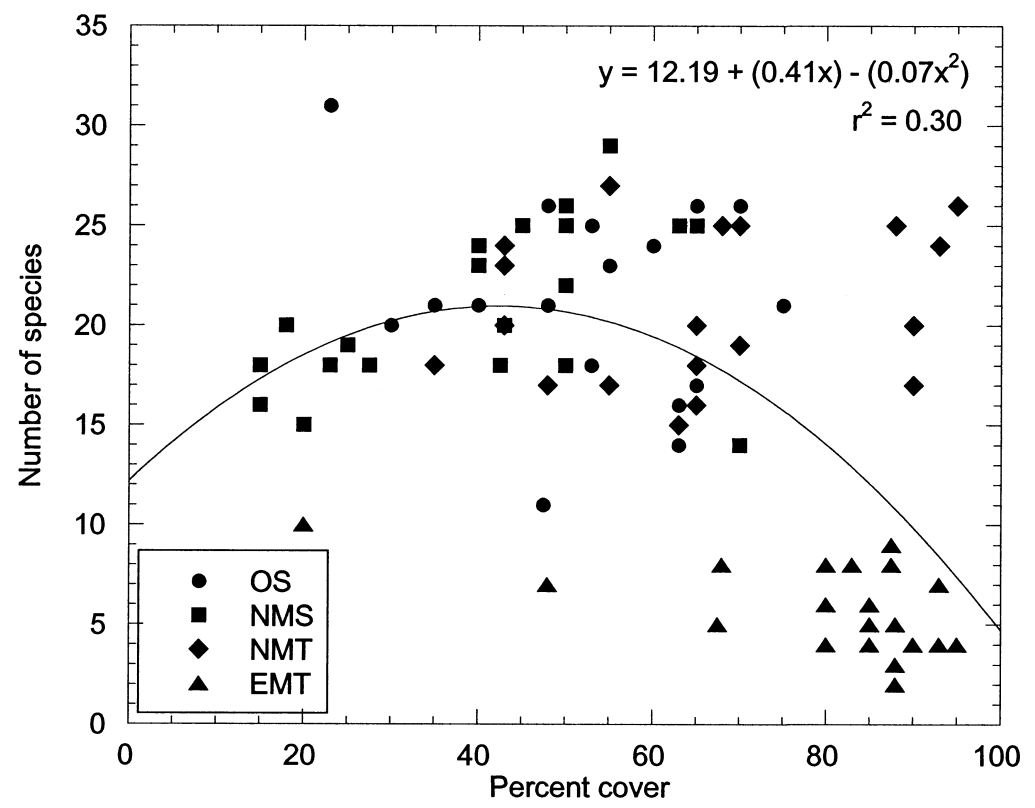

Fig. 5. Relation between percent cover and number of species in each of eighty 1-m² quadrats in 4 community types at the Research Ranch, Arizona. Community types: OS = oak savanna, NMS = native grassland on mesa slopes, NMT $=$ native grassland on mesa tops, EMT $=$ exotic grassland on mesa tops. 
TABle 1. Mean percent canopy cover in 4 community types at the Research Ranch, Arizona. Values represent an average of twenty $1-\mathrm{m}^{2}$ quadrats. Community types: EMT $=$ exotic grassland on mesa tops, NMT $=$ native grassland on mesa tops, OS = oak savanna, NMS = native grassland on mesa slopes. Means followed by the same letter are not significantly different $(\alpha=0.05)$.

\begin{tabular}{lllll}
\hline & \multicolumn{4}{c}{ Community type } \\
\cline { 2 - 5 } & EMT & NMT & OS & NMS \\
\hline Cover $(\%)$ & $79.6 \mathrm{a}$ & $65.5 \mathrm{~b}$ & $53.3 \mathrm{bc}$ & $40.4 \mathrm{c}$ \\
$s$ & 17.73 & 18.30 & 13.96 & 17.05 \\
\hline
\end{tabular}

grassland or oak savanna in physiognomy, just 9 of the 30 were perennial grasses (Table 3). Only 2 of the 30 most frequent species were exotics.

\section{Discussion}

\section{Species Richness at} the Point Scale

At the point scale, average richness ranged from 5.9 species $\cdot \mathrm{m}^{-2}$ to 21.2 species $\cdot \mathrm{m}^{-2}$, with a grand mean of 17.2 species $\cdot \mathrm{m}^{-2}$. These values were not exceptional compared to other grassland sites. Species richness in our quadrats was similar to that at Konza Prairie, for example, where Collins et al. (1998) found 5.6-16.0 species $\cdot 10 \mathrm{~m}^{-2}$ on average. In contrast, Kull and Zobel (1991) reported a maximum of 63 species $\cdot \mathrm{m}^{-2}$ in annually mowed meadows in Estonian grasslands, and Cantero et al. (1999) found up to 89 species $\cdot \mathrm{m}^{-2}$ in mountain grassland in Argentina. At the Research Ranch, Bock et al. (1986) found an average of 6.6 grass species and 7.4 herbaceous species on 36 quadrats in native grassland. Our inventories of forty $1-\mathrm{m}^{2}$ quadrats in NMT produced about the same number of grass species $\left(5.4\right.$ species $\left.\cdot \mathrm{m}^{-2}\right)$ but many more herbaceous species $(15.3$ species . $\mathrm{m}^{-2}$ ). In grassland dominated by exotics, Bock et al. (1986) found 4.8 grass species and 4.4 herbaceous species per quadrat. Our averages in EMT were lower for grass species (1.3 species $\cdot \mathrm{m}^{-2}$ ) and about the same for herbaceous species $\left(4.6\right.$ species $\cdot \mathrm{m}^{-2}$ ). Differences between NMT and EMT were highly significant both for grasses $(t=12.79, P<0.001)$ and for herbaceous species $(t=12.77, P<0.001)$.

Richness of the ten $1-\mathrm{m}^{2}$ quadrats was positively related to total plot richness (Fig. 4) only when the EMT plots were included in the analysis. Otherwise, richness in native com- munities did not predict richness at the point scale, an indication that there was no speciespool effect (Lawton 1999); that is, richness was limited by interactions and processes at the local level rather than by the size of the regional species pool. Richness on the $1-\mathrm{m}^{2}$ quadrats was likely constrained by physical factors that determined plant density such as low soil moisture and seasonal drought.

\section{Species Richness at the Community Scale}

The log-normal shape of the dominancediversity curve (Fig. 3), with few abundant species and many uncommon and rare taxa, was typical of species-rich communities (Whittaker 1975). Comparison with other grassland sites supported that interpretation. Richness at the community scale $\left(1000 \mathrm{~m}^{2}\right)$ was highest in OS $(\bar{x}=121.0$ species $)$ and lowest in EMT $(\bar{x}=$ 52.0 species $)$. NMS $(\bar{x}=92.5$ species $)$ and NMT ( $\bar{x}=77.0$ species) were less rich than OS but still considerably richer than many other grassland communities in temperate zones. Moir and Bonham (1995), for example, found just 29, 30, and 32 species on three $2000-\mathrm{m}^{2}$ plots in desert grassland in New Mexico. Singh et al. (1996) found from 38 to 53 species in $1600-\mathrm{m}^{2}$ plots in short-grass prairie in Colorado. Stohlgren et al. (1998) reported average richness values ranging from 23.7 to 56.5 native species and 1.0 to 9.5 exotic species per $1000-\mathrm{m}^{2}$ plot at 4 plains grassland sites in Colorado, South Dakota, and Montana. In grasslands at high elevations in the Rocky Mountains, Stohlgren et al. (1999) found 9.0-50.0 native species and 0.5-8.5 exotic species per $1000-\mathrm{m}^{2}$ plot. Only a few grassland locations approached the Research Ranch in terms of richness at the community scale. In 200-m² plots at Konza Prairie, Kansas, number of native species per plot averaged 45-65 and reached a maximum of 79-95 (Collins et al. 1998). Cantero et al. (1999) reported average richness values of 57.2-67.4 species per 900- $\mathrm{m}^{2}$ plot in mountain grasslands in Argentina; richness values of 100-130 species were found in about $15 \%$ of the plots.

The species-pool effect may account in part for high richness at the community scale at the Research Ranch. Evidence of this effect is indirect but compelling. First, the regional flora is very rich. High richness at the regional scale 
TABLe 2. Distribution of life forms in 4 community types and 8 plots at the Research Ranch, Arizona. Values represent number of species of each life form. Community types: OS = oak savanna, NMS = native grassland on mesa slopes, $\mathrm{NMT}=$ native grassland on mesa tops, EMT = exotic grassland on mesa tops.

\begin{tabular}{|c|c|c|c|c|c|c|c|c|}
\hline \multirow[b]{3}{*}{ Life form } & \multicolumn{8}{|c|}{ Community type } \\
\hline & \multicolumn{2}{|c|}{ OS } & \multicolumn{2}{|c|}{ NMS } & \multicolumn{2}{|c|}{ NMT } & \multicolumn{2}{|c|}{ EMT } \\
\hline & Plot 1 & Plot 4 & Plot 2 & Plot 6 & Plot 7 & Plot 8 & Plot 3 & Plot 5 \\
\hline Shrub & 7 & 7 & 7 & 4 & 4 & 2 & 5 & 4 \\
\hline Succulent & 3 & 4 & 8 & 4 & 2 & 4 & 2 & 2 \\
\hline Perennial herb & 41 & 57 & 40 & 43 & 34 & 34 & 28 & 27 \\
\hline Perennial grass & 12 & 19 & 18 & 13 & 12 & 17 & 9 & 2 \\
\hline Summer annual & 32 & 35 & 17 & 15 & 11 & 14 & 8 & 6 \\
\hline Winter annual & 10 & 8 & 9 & 5 & 9 & 8 & 5 & 5 \\
\hline Tree & 2 & 3 & 0 & 0 & 0 & 0 & 0 & 0 \\
\hline Biennial & 1 & 1 & 1 & 1 & 2 & 1 & 1 & 0 \\
\hline
\end{tabular}

provides a large number of potential colonizing species, most of which are infrequent within individual communities (Lawton 1999). Measured as the number of species per unit area $\left(\mathrm{S} \cdot[\mathrm{ln} h \mathrm{ha}]^{-1}\right)$, Madrean mixed-grass prairies of southern Arizona are comparable to the richest tall-grass prairie sites and are considerably richer than most short-grass or mixed-grass prairie sites in the central and western United States (Table 4). In comparison to many other grassland sites, therefore, communities at the Research Ranch can draw upon a large species pool. Second, the great majority of species at the community scale occurred in just 1 or 2 plots; very few species were found in all 8 plots (Fig. 2). In other words, high richness at the community scale was not a function of withinquadrat richness, which was not especially high, but rather of variation in species composition between quadrats, often referred to as pattern richness (Whittaker 1977). Third, there was a large number of codominant species within the plots, and no single species showed strong dominance, as measured by frequency (Table 3). Finally, topographic relief at the Research Ranch is small, and there is little variation in soil types; thus, we found high $\beta$ diversity (sensu Whittaker 1977) despite little apparent habitat variation across the landscape.

A second reason for high richness at the community scale in our study was greater sampling effort. We determined cumulative number of species during 2 or 3 years, making 2-3 visits annually. Moir and Bonham (1995), in contrast, estimated species richness on the basis of single 20-minute inventories. Had we stopped sampling at the end of the first year, we would have underestimated species richness by $13 \%$ to $36 \%$ (Fig. 1). Moreover, our spring and summer sampling also augmented richness of our plots. Stohlgren et al. (1998, 1999) sampled their grassland sites once at "peak plant phenology." Elsewhere, this strategy underestimated total species richness by 30\% (West and Reese 1991). At the Research Ranch, most annual herbs and herbaceous perennials bloom between July and September in response to summer rains, but $18 \%$ of perennial herbs and $23 \%$ of annual herbs flower in spring in response to winter rains (data not shown). Had we sampled at the Research Ranch only in summer, we would have overlooked these species. There is inevitably a trade-off between the number of inventories that can be made and the amount of effort that can be invested in each inventory. One-time inventories that provide an instantaneous measure of richness are useful for comparative studies within a region. However, since our objective was to gain a better understanding of regional and global patterns of richness, we chose instead to make intensive and thorough inventories of a few carefully selected areas.

\section{Effect of Exotics on Richness}

Our study did not duplicate recent research suggesting that numbers of native and exotic species are positively correlated in a variety of communities and at several scales (Lonsdale 1999, Stohlgren et al. 1999, Sax 2002). Exotic species were only a small proportion $(7.4 \%)$ of the total flora of the Research Ranch (McLaughlin et al. 2001) and were mostly associated with disturbances, such as roadsides, wells, and cattle 


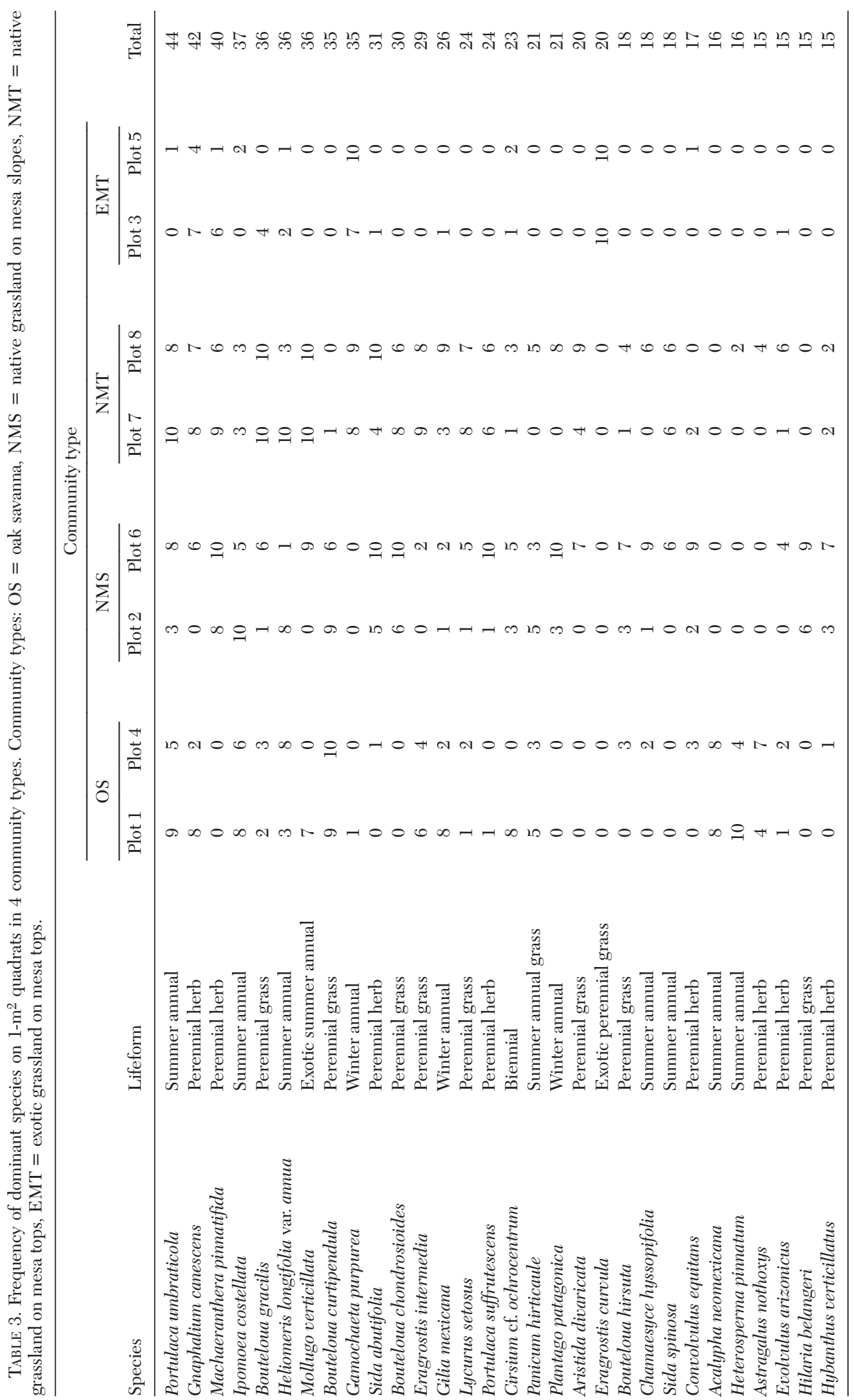




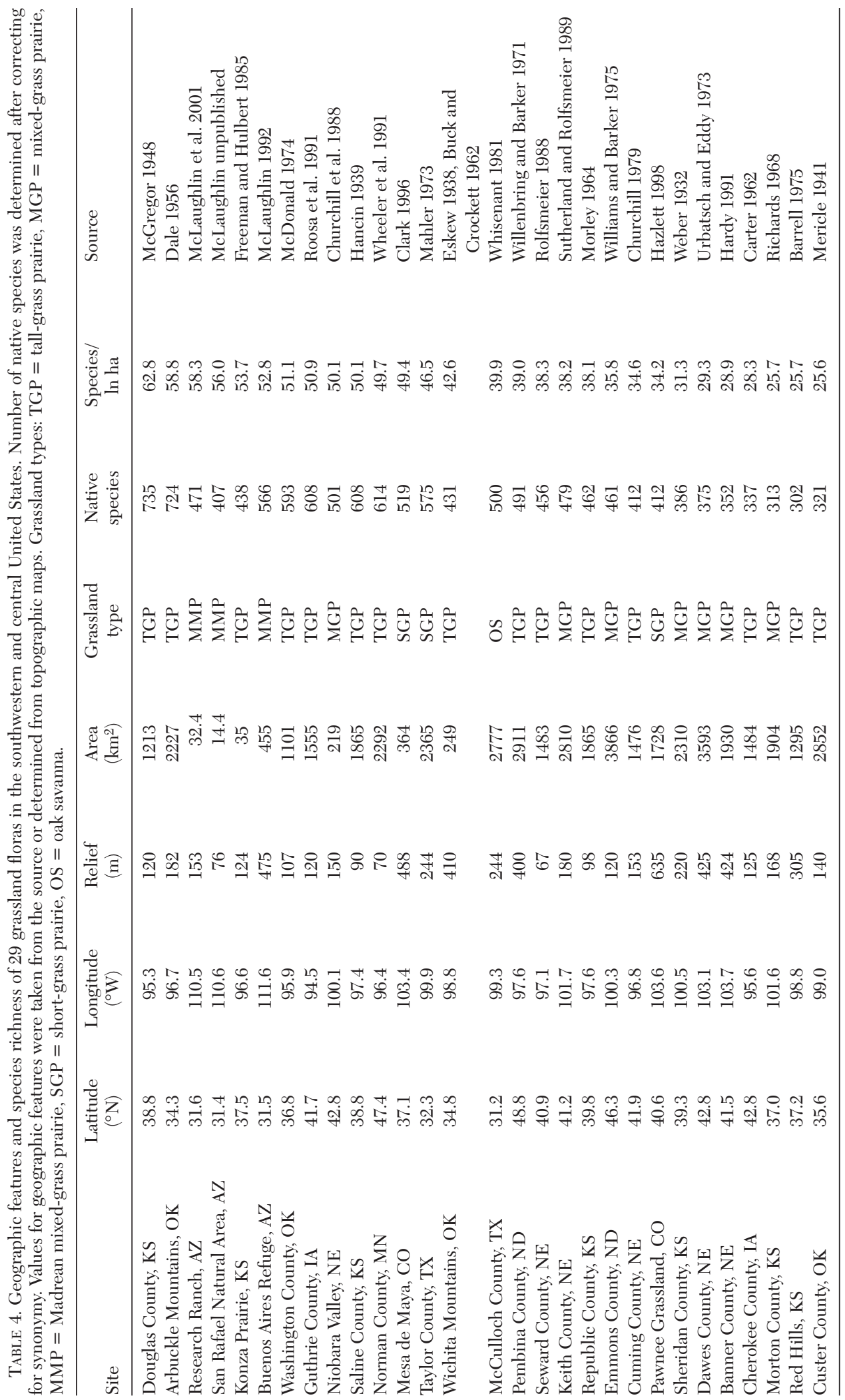


tanks. Our plots, purposely located in undisturbed habitats, supported very few (1-4) species of exotics, and communities dominated by E. curvula were no more likely than others to contain additional exotic species.

At the community scale, we did not find significant differences in richness between 1000- $\mathrm{m}^{2}$ plots dominated by E. curvula and those dominated by native species, with the exception of the OS plots, which were more than twice as rich on average as the EMT plots. Oak savanna is a notably rich community type in Arizona (Bowers and McLaughlin 1982). At the Research Ranch, it is found in shallow drainages and on slopes in major ravines, habitats that are topographically very different from the dry mesa tops where $E$. curvula dominates. In terms of topography, the NMT plots were much more similar to the EMT plots, providing a more equitable comparison. Despite marked differences in lifeform diversity between NMT and EMT (Table 2; see also Bock and Bock 1986), the 2 community types did not differ significantly in species richness $(P=0.065)$, even though NMT averaged 25 more species per plot than EMT. The NMT plots were established 1-2 years after the EMT plots. Had we monitored all plots for an equal length of time, native grassland on mesa tops might well have been significantly richer than exotic grassland in the same habitat.

The effect of $E$. curvula on overall richness was readily apparent at smaller scales; $1-\mathrm{m}^{2}$ quadrats dominated by this exotic species were substantially poorer than those dominated by natives. As noted above, average number of grass and herbaceous species in 40 quadrats was significantly higher in NMT than in EMT. Bock et al. (1986) similarly found significantly fewer grass and herbaceous species in a sample of quadrats from grasslands dominated by exotic species. Theoretically, exotics are most likely to reduce overall species richness in communities with low primary productivity, such as deserts and semiarid grasslands, but, even then, natives are unlikely to be displaced unless exotics somehow change disturbance regimes (Huston 1994). At the Research Ranch, however, we saw no evidence of altered disturbance regimes. At the start of our study, the EMT plots had not burned for at least 11 years, more than enough time for return to normal cover and density of grasses and herbs (Bock and Bock 1992a, 1992b). Domestic livestock had been absent for 29 years. We believe that native species richness was reduced on the EMT quadrats, not because exotics changed disturbance regimes, but because these sites had been plowed and seeded with E. curvula in 1949. After the initial disturbance, native species were evidently unable to displace $E$. curvula, which at the start of our study remained dominant where it had been sown nearly 50 years earlier.

We did not investigate specific mechanisms underlying low richness in the EMT quadrats, but our observations suggest 2 likely possibilities: competition and allelopathy. Competition is frequently invoked to explain the impact of exotic plants on native plant communities (Levine et al. 2003). At the Research Ranch, high cover of $E$. curvula compared to native grasses (Bock et al. 1986) suggests that there is a strong potential for competitive exclusion. Experimental work indicates that E. curvula can indeed be a strong competitor. In a replacement-series experiment with the perennial grass Anthephora pubescens Nees, E. curvula gained a large competitive advantage from its higher leaf area index, leaf area duration, crop growth rate, number of lateral tillers, and tuft height (Mynhardt et al. 1994). Observations in Australian pastures indicated that E. curvula can have a marked effect on soil water balance at a depth of $100 \mathrm{~cm}$, affecting patterns of deep drainage (Johnston et al. 2002). In southeastern Arizona, E. curvula becomes active in late spring, whereas most native perennial grasses do not grow or flower until summer rains are well underway. By pre-empting soil moisture before the start of the summer rainy season, E. curvula might interfere with growth of native grasses.

Despite high cover in the EMT quadrats, there was still much bare ground available for other species to occupy, suggesting that alleopathic effects might have excluded certain species, especially the summer annuals, perennial herbs, and perennial grasses that are underrepresented on EMT plots (Table 2). Aqueous root or shoot extracts of several invasive grasses, including Cynodon dactylon (L.) Pers. (Kalita et al. 1999), Sorghum halepense (L.) Pers. (GamezGonzalez et al. 2002), and Imperata brasilensis Trin. (Casini et al. 1998), reduced germination 
and seedling growth of various cultivated plants such as rice, wheat, and beans. Moreover, leachate from seeds of E. curvula suppressed germination of a leguminous herb (Murray 1998). At the Research Ranch, E. curvula may have similar effects on species that germinate during the warm season; such species would include all summer annuals and most perennial herbs and grasses.

Whatever the cause of reduced plant species richness in exotic grassland at our study site, the impoverishment is likely to perpetuate itself. In California, native annual forbs in former grasslands were strongly seed-limited (Seabloom et al. 2003); we suspect that the same is true of summer annuals and native perennial grasses at the Research Ranch. In contrast to seeds of exotic lovegrasses, which have a high degree of dormancy (Weaver and Jordan 1986, Voigt et al. 1996) and probably persist in the soil for several years, seeds of most native perennial grasses are transient in the soil, forming small seed banks or none (Major and Pyott 1966, Rabinowitz 1981, Hassan and West 1986, O'Shea-Stone 1988, Coffin and Lauenroth 1989, Kinucan and Smeins 1992). Therefore, once competition, allelopathy, or some other process eliminates native grasses from a site, they are unlikely to recover, especially given their low rates of seedling survival in undisturbed stands of exotic grasses (Biedenbender and Roundy 1996). Some summer annuals may also possess short-lived seeds (e.g., Freas and Kemp 1983), and, unless dispersal brings additional seeds into the community, they too are likely to disappear. We believe that ecological interactions such as competition and allelopathy have gradually depleted the seed banks of native species over the approximately 50 -year period that $E$. curvula has dominated these sites.

\section{ACKNOWLEDGMENTS}

We thank E. Geiger, L. Kennedy, B. Lewis, D. Noel, B. Plemons, and K. Pokorny for assistance in the field; $\mathrm{B}$. Branan for permission to work at the Research Ranch; and J. Bock and L. Kennedy for reading and commenting on the manuscript.

\section{Literature Cited}

Anable, M.E., M.P. McClaran, and G.B. Ruyle. 1992. Spread of introduced Lehmann lovegrass Eragrostis lehmanniana Nees. in southern Arizona, USA. Biological Conservation 61:181-188.
Audubon Research Ranch. 2003. Invasive species. Accessed 1 September 2004. Available from: http:// www.audubon.org

BarReLL, J. 1975. The Red Hills of Kansas: crossroads of plant migrations. Natural Land Institute, Rockford, IL.

Biedenbender, S.H., And B.A. Roundy. 1996. Establishment of native semidesert grasses into existing stands of Eragrostis lehmanniana in southeastern Arizona. Restoration Ecology 4:155-162.

Bock, C.E., AND J.H. Bock. 2000. The view from Bald Hill: thirty years in an Arizona grassland. University of California Press, Berkeley.

Bock, C.E., J.H. Bock, K.L. Jepson, and J.C. Ortega. 1986. Ecological effects of planting African lovegrasses in Arizona. National Geographic Research 2:456-463.

Bock, J.H., AND C.E. Bock. 1986. The Appleton-Whittell Research Ranch Sanctuary of the National Audubon Society. Desert Plants 8:47-48.

1992a. Vegetation responses to wildfire in native versus exotic Arizona grassland. Journal of Vegetation Science 3:439-446.

1992b. Short-term reductions in plant densities following prescribed fire in an ungrazed semidesert shrub-grassland. Southwestern Naturalist 37:49-53.

Bowers, J.E., AND S.P. MCLaughlin. 1982. Plant species diversity in Arizona. Madroño 29:227-233.

Brown, D.E. 1982. Biotic communities of the American Southwest-United States and Mexico. Desert Plants 4:1-342.

Buck, P., AND J.J. CRockett. 1962. Some additions to Eskew's list of flowering plants of the Wichita Mountains Wildlife Refuge. Proceedings of the Oklahoma Academy of Science 43:41-42.

Cable, D.R. 1971. Lehmann lovegrass on the Santa Rita Experimental Range, 1937-1968. Journal of Range Management 24:17-21.

Cantero, J.J., M. Pärtel, And M. Zobel. 1999. Is species richness dependent on the neighbouring stands? An analysis of the community patterns in mountain grasslands of central Argentina. Oikos 87:346-354.

Carter, J.L. 1962. The vascular flora of Cherokee County. Iowa Academy of Science 69:60-70.

Casini, P., V. Vecchio, AND I. TAmantini. 1998. Allelopathic interference of itchgrass and cogongrass: germination and early development of rice. Tropical Agriculture 75:445-451.

Churchill, S.P. 1979. A botanical survey of Cuming County: part I, the vascular plants. Transactions of the Nebraska Academy of Sciences 4:43-51.

Churchill, S.P., C.C. Freeman, and G.E. Kantak. 1988. The vascular flora of the Niobara Valley Preserve and adjacent areas in Nebraska. Transactions of the Nebraska Academy of Sciences 16:1-15.

CLARK, D.A. 1996. A floristic survey of the Mesa de Maya region, Las Animas County, Colorado. University of Colorado Museum, Boulder.

Coffin, D.P., and W.K. Lauenroth. 1989. Spatial and temporal variation in the seed bank of a semiarid grassland. American Journal of Botany 76:53-58.

Collins, S.L., A.K. KNapP, J.M. Briggs, J.M. Blair, and E.M. Steinauer. 1998. Modulation of diversity by grazing and mowing in native tallgrass prairie. Science 280:745-747.

DALE, E.E. 1956. A preliminary survey of the flora of the Arbuckle Mountains, Oklahoma. Texas Journal of Science 9:41-73. 
Eskew, C.T. 1938. The flowering plants of the Wichita Mountains Wildlife Refuge. American Midland Naturalist 20:695-703.

Freas, K.E., AND P.R. Kemp. 1983. Some relationships between environmental reliability and seed dormancy in desert annual plants. Journal of Ecology 71:211217.

Freeman, C.C., And L.C. Hulbert. 1985. An annotated list of the vascular flora of Konza Prairie Research Natural Area, Kansas. Transactions of the Kansas Academy of Science 88:84-115.

Gamez-Gonzalez, H., F. Zavala-Garcia, R.K. Maiti, S. Moreno-Limon, D.E. Lozano-Del Rio, and S. Martinez-Lozano. 2002. Effects of extracts of Cynodon dactylon L. and Sorghum halepense L. on cultivated plants. Crop Research (Hisar) 23:382-388.

GENTRY, A.H. 1988. Changes in plant community diversity and floristic composition on environmental and geographical gradients. Annals of the Missouri Botanical Garden 75:1-34.

Hancin, J. 1939. Flora of Saline County: ferns and flowering plants. Transactions of the Kansas Academy of Science 42:139-149.

HaRdy, J.P. 1991. The vascular flora of Banner County, Nebraska. Transactions of the Nebraska Academy of Science 18:109-126.

Hassan, M.A., and N.E. West. 1986. Dynamics of soil seed pools in burned and unburned sagebrush semideserts. Ecology 67:269-272.

Hazlett, D.L. 1998. Vascular plant species of the Pawnee National Grassland. USDA Forest Service, General Technical Report RMRS-GTR-17, Fort Collins, CO.

Huston, M.A. 1979. A general hypothesis of species diversity. American Naturalist 113:81-101.

1994. Biological diversity: the coexistence of species on changing landscapes. Cambridge University Press, Cambridge, England.

1999. Local processes and regional patterns: appropriate scales for understanding variation in the diversity of plants and animals. Oikos 86:393-401.

Johnston, W.H., T.B. Koen, AND V.F. Shoemark. 2002. Water use, competition, and a temperate-zone $\mathrm{C}_{4}$ grass (Eragrostis curvula [Schrad.] Nees complex cv. Consol). Australian Journal of Agricultural Research 52:715-728.

Kalita, D., H. Choudhury, and S.C. Dey. 1999. Allelopathic effectiveness of some common rice weed species on germination, radicle and plumule growth of rice (Oryza sativa L.) seed. Crop Research (Hisar) 17:183-187.

Kinucan, R.J., And F.E. Smeins. 1992. Soil seed bank of a semiarid Texas grassland under three long-term (36years) grazing regimes. American Midland Naturalist $128: 11-21$.

Klimes, L., M. Dancak, M. HajeK, I. Jongepierova, and T. KuCERA. 2001. Scale-dependent biases in species counts in a grassland. Journal of Vegetation Science 12:699-704.

Kull, K., AND M. Zobel. 1991. High species richness in an Estonian wooded meadow. Journal of Vegetation Science 2:711-714.

LAWTON, J.H. 1999. Are there general laws in ecology? Oikos 84:177-192.

Levine, J.M., M. Vila, C.M. D’Antonio, J.S. Kukes, K. GRIGUlis, AND S. LAVOREL. 2003. Mechanisms underlying the impacts of exotic plant invasions. Proceed- ings of the Royal Biological Sciences, Series B 270: $775-781$.

LONSDALE, W.M. 1999. Global patterns of plant invasions and the concept of invasibility. Ecology 80:1522-1536.

Loreau, M. 2000. Are communities saturated? On the relationship between $\alpha, \beta$ and $\gamma$ diversity. Ecology Letters 3:73-76.

MahleR, W.R. 1973. Flora of Taylor County, Texas: a manual of the vascular plants with selected sketches. Biology Department, Southern Methodist University, Dallas, TX.

Major, J., AND W.T. PyotT. 1966. Buried, viable seeds in two California bunchgrass sites and their bearing on the definition of a flora. Vegetatio 13:253-282.

McDonald, C.B., III. 1974. A floristic study of the native or naturalized angiosperm plants of Washington County, Oklahoma. Master's thesis, Oklahoma State University, Stillwater.

McGregor, R.L. 1948. The flora of Douglas County, Kansas. Transactions of the Kansas Academy of Science 51:77-106.

McLaughlin, S.P. 1992. Vascular flora of Buenos Aires National Wildlife Refuge (including Arivaca Cienega), Pima County, Arizona. Phytologia 73:353-377.

McLaughlin, S.P., E.L. Geiger, and J.E. Bowers. 2001. A flora of the Appleton-Whittell Research Ranch, northeastern Santa Cruz County, Arizona. Journal of the Arizona-Nevada Academy of Science 33:113-131.

MERICLE, L.W. 1941. The spermatophytes of Custer County, Oklahoma. Master's thesis, University of Oklahoma, Norman.

MoIR, W.H., AND C.D. Bonham. 1995. Diversity indices applied in desert grassland communities of Otero Mesa, New Mexico. Pages 42-49 in N.E. West, editor, Biodiversity on rangelands. Natural resources and environmental issues. Volume 4. Utah State University, Logan.

Morley, G.E. 1964. A floristic study of Republic County, Kansas. Transactions of the Kansas Academy of Science 67:716-746.

Murray, B.R. 1998. Density-dependent germination and the role of seed leachate. Australian Journal of Ecology 23:411-418.

Mynhardt, J.E., M.W. Van Rooyen, and G.K. Theron. 1994. Competitive ability of two grass species: Anthephora pubescens and Eragrostis curvula: 1. Yield and biomass allocation. South African Journal of Botany 60:261-268.

O'Shea-Stone, M. 1988. The seed banks in a semidesert grassland of southeastern Arizona and its relationship to the seed rain and vegetation. Master's thesis, University of Colorado, Boulder.

Rabinowitz, D. 1981. Buried viable seeds in a North American tall-grass prairie: the resemblance of their abundance and composition to dispersing seeds. Oikos 36 : 191-195.

RiCHARDS, E.L. 1968. Vascular plants of Morton County, Kansas. Transactions of the Kansas Academy of Science 71:154-165.

Rolfsmeier, S.B. 1988. The vascular flora and plant communities of Seward County, Nebraska. Transactions of the Nebraska Academy of Sciences 16:91-113.

Roosa, D.M., L.J. Eilers, and S. ZaGer. 1991. An annotated checklist of the vascular plant flora of Guthrie County, Iowa. Journal of the Iowa Academy of Science 98:14-30. 
SAX, D.F. 2002. Native and naturalized plant diversity are positively correlated in scrub communities of California and Chile. Diversity and Distributions 8:193210.

Seabloom, E.W., E.T. Borer, V.L. Boucher, R.S. Burton, K.L. Cottingham, L. Goldwasser, W.K. Gram, eT AL. 2003. Competition, seed limitation, disturbance, and reestablishment of California native annual forbs. Ecological Applications 13:575-592.

Singh, J.S., P. Bourgeron, and W.K. Lauenroth. 1996. Plant species richness and species-area relations in a short-grass steppe in Colorado. Journal of Vegetation Science 7:645-650.

Stohlgren, T.J., K.A. Bull, Y. Otsuki, C.A. Villa, And M. LEE. 1998. Riparian zones as havens for exotic plant species in the central grasslands. Plant Ecology 138:113-125.

Stohlgren, T.J., L.D. Schell, and B.V. Huevel. 1999. How grazing and soil quality affect native and exotic plant diversity in the Rocky Mountain grasslands. Ecological Applications 9:45-64.

SutherLand, D.M., AND S.B. Rolfsmeier. 1989. An annotated list of the vascular plants of Keith County, Nebraska. Transactions of the Nebraska Academy of Sciences 17:83-101.

Tilman, D. 1982. Resource competition and community structure. Princeton University Press, Princeton, New Jersey.

. Species richness of experimental productivity gradients: how important is colonization limitation? Ecology 74:2179-2191.

Urbatsch, L.E., AND R. EdDy. 1973. A floristic study of Dawes County, Nebraska. Transactions of the Nebraska Academy of Sciences 2:190-204.

Voigt, P.W., C.R. Tischler, and M.M. Poverene. 1996. Seed dormancy and its alleviation in lovegrass hybrids. Crop Science 36:1699-1705.
WEAVER, L.C., AND G.L. JoRDAN. 1986. Effects of selected seed treatment of germination rates of five range plants. Journal of Range Management 38:415-418.

Weber, C. 1932. The flora of Sheridan County, Kansas. Transactions of the Kansas Academy of Science 35:161-178.

West, N.E., AND G.A. ReEse. 1991. Comparison of some methods for collecting and analyzing data on aboveground net production and diversity of herbaceous vegetation in a northern Utah subalpine context. Vegetatio 96:145-163.

Wheeler, G.A., R.P. Dana, AND C. Converse. 1991. Contribution to the vascular and moss flora of the Great Plains: a floristic survey of six counties in western Minnesota. Michigan Botanist 30:75-129.

Whisenant, S.G. 1981. The vascular flora of McCulloch County, Texas. Texas Journal of Science 33:197-220.

Whittaker, R.H. 1975. Communities and ecosystems. MacMillan, New York. . 1977. Evolution of species diversity in land communities. Evolutionary Biology 10:1-67.

Willenbring, R.E., AND W.T. BARKER. 1971. The vascular flora of Pembina County, North Dakota. Master's thesis, North Dakota State University, Fargo.

Williams, R.P., AND W.T. BarKer. 1975. Vascular flora of Emmons County, North Dakota. Prairie Naturalist 7:17-78.

WRCC (Western Regional Climate Center). 2004. Arizona climate summaries. Accessed 1 September 2004. Available from: http://www.wrcc.dri.edu

Received 7 January 2005 Accepted 9 May 2005 